\title{
The Dfpartment of THE American Conference of Pharmaceutical Faculties
}

[EDiToR's Note.-The editor asked Prof. Zada M. Cooper, of the University of Iowa, to enumerate, first, a list of books and periodicals which she considered absolutely essential as a nucleus for a pharmaceutical library; secondly, to state what type of books and periodicals in pharmacy and the related sciences should be added as the library grows beyond the bare fundamentals necessary for a working library. We appreciate the tangibleness of her answer.

Dean Edward Spease of Western Reserve University, has complied with the editor's request for an expression as to what he thinks "Experience" should consist of in the training of a modern pharmacist.

In September 1921 the University of Washington at Seattle dropped the two-year course in pharmacy. Dean C. W. Johnson's description of the effects which this had upon registration, upon the attitude taken by the student body, and upon the sympathetic position taken by the pharmacists and laymen of the state, will be read with intense interest by every one interested in advancing professional and educational requirements for pharmacy.

Rufus A. Lyman, Chairman Executive Committee and Conference Editor.]

\section{BOOKS ESSENTIAL FOR A PHARMACEUTICAL, LIBRARY. BY ZADA M. COOPER.}

Certain books and periodicals are absolutely essential for the beginning of a library in any college of pharmacy, the "irreducible minimum" in other words. No two people would agree on such a list, for the making of it is somewhat like selecting the ten best novels or the ten best essays in English literature. However, each would choose two or three that he believed to be best on each subject. The submission of this list may call forth an avalanche of criticism but if any of us are benefited the writer should be satisfied.

\footnotetext{
Thited States Pharmacopoeia VII, VIII and IX.

National Formulary III and IV.

National Standard Dispensatory.

United States Dispensatory.

British Pharmacopoeia.

German Pharmacopoeia.

British Pharmaceutical Codex.

Remington-Practice of Pharmacy.

ARNX-Principles of Pharmacy.

Caspari-Treatise on Pharmacy.

ScovILLE-Art of Compounding.

RudDIMAN-Incompatibilities in Prescriptions.

STURMER-Pharmaceutical Arithmetic.

Srevens-Arithmetic of Pharmacy.

SrURMER-Pharmaceutical Latin.

MERCK- 1907 Index.

HOLLEMAN-COOPER-Inorganic Chemistry.

SMITH (ALEXANDER)-Inorganic Chemistry.

CADY-Inorganic Chemistry.

COHEN-Organic Chemistry.

ClARKE-Organic Chemistry.

NorRis--Organic Chemistry.

Ricater--Organic Chemistry.

Noyes-Organic Chemistry.

SUdBorovgh and JAMES-Practical Organic Chemistry.

ScenpF-Qualitative Aralysis.

Scrmpr-Volumetric Analysis.

COBLENTz-Volumetric Analysis.

OrSEN-Quantitative Chemical Analysis.

BLoxaM-Chemistry, Inorganic and Organic.
}

TREADWELL and Hali,-Analytical Chemistry, Qualitative.

Treadwell and HaLL-Analytical Chemistry, Quantitative.

Gooch-Methods in Chemical Analysis.

DAGgeTT-Pharmaceutical Chemistry.

Stanislaus and KIMBERLY-Pharmaceutical Chemistry.

SADTLER and CoBLENTZ-Pharmaceutical and Medical Chemistry.

ConN-Indicators and Test Papers.

MULLIKEN-Identification of Pure Organic Compounds, Vols, I, II, III.

ShERMAN-Organic Analysis.

ALLEN--Commercial Organic Analysis, Vols. I to IX.

LEACH-Food and Drug Analysis.

FuLLER-Chemistry and Analysis of Drugs and Medicines.

NELson-Analysis of Drugs and Medicines.

Lyon--Practical Standardizing of Organic Drugs.

AsrLeEY-Chemical Calculations.

MERck-Chemical Reagents, Their Purity and Tests. MurRay-Standards and Tests for Reagent Chemicals. SEIDELI-Solubilities of Inorganic and Organic Substances.

Cushny-Pharmacology and Therapeutics.

POTTER-Therapeutics, Materia Medica and Pharmacy.

Bastedo-Materia Medica.

WILEERT-Pharmacology of Useful Drugs. 
Francis-Fortescute-Brickdal,E-Chemical Basis of Pharmacology.

CULBRETH-Materia Medica and Pharmacology.

Kraemer-Scientific and Applied Pharmacognosy.

SAYR:-Materia Medica and Pharmacognosy.

YOUNCKEN-Pharmacognosy.

YotNGKEN-Pharmaceutical Botany.

GRAY-Manual of Rotany.

Maceride-I.essons in Hotany.

BASTIN-College Botany.

HAWK -Physiological Chemistry.

HAMMERSTEN and HEDIN-Physiological Chemistry.

A bDerhalden-Physiological Chemistry.

RockwOOD-Physiological Chemistry.

Simon-Physio.ogical Chemistry.

JURDAN- General Bacteriology.

SCHNFIDER-Pharmaceutical Bacteriology.

Srrrr-Practical Bacteriology, Blood Work and Animal Parasitology.

MACLEOD-Physiology.

Gindemeister and Hoffman-Volatile Oils.

LEwkowrtsch-Chemical Technology of Oils, Fats and Waxes.

FuLER-POPE-Chemistry of the binzymes.
Conherm-Enzymes.

MrrChELL-Modern Urinology.

GradwoHL-Blood and Urine Chemistry.

MolinarI-Industrial Chemistry, Inorganic.

MoLinari-Industrial Chemistry, Organic.

Rogkrs-Industrial Chemistry.

PICTET and BrDdLe-Vegetable Alkaloids.

WeBSTRR-International Dictionary.

LipPINeorT-Medical Iictionary.

WEBnER-Technical Dictionary (English, French, Italian, Crermau).

Frditorial Staff of Chemical Ingineering CatalogChemical Dictionary.

JACKson-Glossary of Botanic Terms.

Lyons-Plant Names, Scientific and Popular.

RAND and MCNALLY - Atlas of the World.

Journal, of the American Pharmaceutical, AssoCiation, Volumes 1 to 10 (1912-1921).

Druggists' Circular, volumes 61 to 65 (1917-1921).

A merican Druggist and Pharmaceutical Record, Volumes 6.5 to $69(1917-1921)$.

American Journal of Pharmacy, Volumes 89 to 93 $(1917-1921)$.

Besides the complete volumes of the journals just mentioned the library should be receiving the current issues of each and also Drug and Chemical Markets and Merck's Report. Many more ought to be included: these seem to me the very smallest number allowable.

This list of books is selected chiefly with the student in mind but no library can be limited to books for student use only. When the needs of the teaching staff are considered the list grows larger and more varied.

If I were asked to say what sort of books the library of a college of pharmacy should contain, I should add numerous other lines not touched at all in the above list. When one remembers that pharmacy touches life at many points, the scope grows broad.

There should be a historical section containing histories of pharmacy like "Wootton's Chronicles," histories of medicine and histories of chemistry. Another section should be devoted to biography: lives of eminent pharmacists, physicians and chemists. Fiction, too, has its place; any story that touches in any way any phase of pharmacy or chemistry or medicine or in which pharmacists are depicted should be included.

There should be books on water analysis, dairy products, microscopy, physics and photography; dyes, pigments, varnishes, bleaching and cleaning; economies, accounting, arithmetics of pharmacy, chemistry and business; correspondence, advertising, and show card writing. There must be a shelf devoted to laws affecting pharmacy and pharmacists. Several others will be filled with formularies. Government bulletins contain much valuable information and the various publications of the Council of Pharmacy and Chemistry of the American Medical Association are a necessity.

The list given above seems pitifully small but since the biggest and finest libraries have small beginnings these might constitute the nucleus.

The library of the College of Pharmacy at Iowa University is not large, numbering only forty-three hundred volumes, but considering the comparative youth of the college and the fact that most of the material is of value now and is being used 
now, it perhaps makes a creditable showing. A few years ago we completed our sets of a few of the leading journals as well as those of the leading dispensatories and the "United States Pharmacopoeia." Aside from these we have little that is old and we are getting each new thing or each new edition of every worth-while book as soon as possible after it is off the press.

We get regularly about thirty journals. 'These include all of the best pharmaceutical journals published in this country, two English, one Canadian, one Australian and one German. All are pharmacentical except three, the Journal of the American Medical Association, the Journal of Pharmacology and Therapentics and The Merchants Record and Show Hindow. No chemical journals are taken because the department of chemistry gets those and they are accessible to students of pharmacy, the chemical library opening directly from the laboratory of general chemistry. Incidentally it might be added that there are in the chemical library several thousand volumes on strictly chemical subjects and files of all the leading chemical journals for a number of years. Approximately half of the pharmaceutical journals are being bound, the less important ones, particularly those that are not indexed, being omitted.

Our library is largely used. Every studęnt in the college spends some time there and the better ones many hours. The library opens into the main pharmaceutical laboratory and throughout laboratory periods students come and go for a few minutes at a time. During vacant periods between classes and at other times the room is filled with students at work. No "library reading course" is given and there is no specific requirement about the amount of reading to be done. When our shortest course becomes one of three years such a course may possibly be given. Most courses, particularly recitations in practical pharmacy which are correlated with actual laboratory work, give opportunity for use of many reference works. This is especially true of all work after the first year. Many preparations are made by unofficial formulas and for all of these as well as many official ones reference reading becomes important. It is still more true of drug assaying and all third and fourth year work.

Surely a good library is as important a part of a college of pharmacy as its laboratory equipment.

State Lniversity of IOWA, IOWA CiTY, IOWA.

\section{THE EXPERIENCE CHIMERA.}

BY EDWARD SPEASE.

Had I been asked to write such an article as this ten years ago I should have responded with alacrity, for then as a laboratory assistant I felt I knew all things pharmaceutical, but in these days I find even I can take another's suggestion occasionally and profit by it.

Before one attempts to discuss the value of "experience," or its lack of value, it might be well to think a moment about what the word "experience" in pharmacy means. Also would it not be well to discuss just what advocates of compulsory experience mean by it?

Fxperience in pharmacy really means practice in the manufacturing of substances intended for direct sale or to be used in prescriptions, the compounding 
of actual prescriptions and the rendering of pharmaceutical service to the physician and to the public. Experience or time spent in a retail drug store may mean the above alone or this coupled with experience in merchandising or it may mean merchandising only. It may mean merchandising experience such as can be obtained in a grocery or a meat market.

No one will gainsay the fact that a young man or woman who has never been in a retail store, no matter what his education, is not as proficient as one who has been in one for some months or some years. This experience is, then, ability to put dollars into the owner's cash register. Is this the experience teachers and boards are talking about or is it the experience meant when mentioned by the retail trade?

I believe we are not all talking about the same thing. As to experience in retail merchandising, $I$ am willing to grant to the retail druggist that it is a desirable asset to find in a clerk one is about to bire, though even then sometimes the druggist may have to overcome some undesirable experience. Much can be said upon this particular kind of experience. One might add that to require such an apprenticeship will guarantee cheap help in the store.

Some druggists base salaries upon the years of experience. I sometimes question the wisdom of both the cheap help and the years of experience when neither is coupled with ability, general education and personality. I firmly feel that many stores, even though successful, would be eminently more so if they secured services of men who were better educated and not just hand trained. I also firmly feel that it is better for a store to start in with a clerk who has had an education than to start in with one who merely wishes a job and thinks he would like pharmacy, or perchance one who cannot enter any type of school or training and takes up the drug store as a last resort.

I wonder how many druggists interview a boy, when expecting to start one in the store, with only the idea in mind as to whether he can make a satisfactory clerk or errand boy, and not as to whether he will make a pharmacist as well. Is he fitted with health, character and antecedents sufficient to build a pharmaceutical career upon? How many druggists in the past have taken in a knotty stick and have then been disappointed because a school feels that it is wasting its time and valuable equipment in trying. to turn out a serviceable piece of furniture? There is such a thing as school efficiency as well as business efficiency.

A school must select its raw material if the world is to put the stamp of approval and satisfaction upon the finished product. If others, as retail druggists, are to select the raw material, then it must be according to approved specifications.

The board must serve as the final inspectors of finished products and must not set the standards so low that the market will be flooded with shoddy material.

If a school so arranges its curriculum that a student learns to manufacture, compound and dispense, and thus becomes a proficient pharmacist, why require this student to learn to merchandise in things other than pharmaceutical products before giving him final inspection by the boards and permitting him to practice? Are we aiming by experience to give the druggist an efficient salesman or are we expecting to give the public safe pharmaceutical service? If one attends school every day throughout the academic year for four years and is graduated and the 
board pronounces him proficient, why require this other thing that we all know is unworthy of us?

If the school course is solely didactic, as was the case once upon a time, the laboratory (store) experience becomes a necessity, but the time for this is gone by.

A few three-month places, so-called schools, still exist, but these will be eliminated as fast as the personnel of our boards (inspectors of finished products) become sufficiently educated to recognize high-class material from that covered up with showy paint. I do not make this statement to reflect upon any board member but merely to bring home the fact that the pharmaceutical practice or experience should be gained in the schools, in their laboratories and in the connecting hospitals. If the school does not furnish such experience students must be sent to the drug store before they are turned out as finished products.

Once more let me reiterate my opinion that the day of the need for $e^{-}$ perience of the kind most often mentioned is gone by and the experience most often referred to is merely a chimera. I,et us have educated men and women in pharmacy and keep in mind that the youth coming to us is no longer deluded by this time-worn excuse to keep him from the place where he belongs.

WESTERN RESERVE UNIVERSTTY, CleEVELAND, OHo.

THE, THREE-YEAR COURSE AT THE, UNIVERSITY OF WASHINGION COI.LEGE OF PHARMACY.

BY C. W. JOHNSON.

The University of Washington College of Pharmacy decided about the middle of the school year of 1920-21 to drop the two-year course. This action was taken after thorough discussion by our faculty and a careful investigation of the probable effects of this action, by securing opinions from students then enrolled in the college, alumni and other practical pharmacists in the state and of principals of several of the high schools. It is possible that this college of pharmacy is more fortunately located than some other colleges of the country, but we learned by investigation in the high schools that students expecting to go to the university thought only in terms of a four-year course. The practical pharmacists expressed themselves as being in favor of more extended training, particularly so, if part of it could be training for the business side of pharmacy. Many of the freshmen then in college as candidates for the two-year degree stated that if the two-year course were dropped they would not want to receive the two-year degree but would continue for the three- or four-year degree.

With this data in mind we decided to make the change and not give notice in advance in order to attract a large "last" class for the shorter course. This change was announced in the bulletin of the college for 1921-22, issued in the spring of 1921, merely by not including a two-year curriculum. Notice was given the drug trade through the Pacific Drug Review and at the annual meeting of the Washington State Pharmaceutical Association.

We were, of course, much interested to get the final figures of enrolment at the opening of the present college year and were well satisfied to learn that the freshmen enrolment of fifty-four for the three-year course was only ten less than the freshmen enrolment of the year previous when most of them, presumably were 
entering for the two-year course only. It is also worthy of notice that the total enrolment of the college showed a gain over the previous year and that the College of Pharmacy was the only college in the University that showed such a gain, the loss in enrolment in the University as a whole being due to stringent financial conditions of this section of the country and to higher tuition fees for all students which kept many students out of college.

We have at the University of Washington a well-organized and very popular College of Business Administration. It occurred to the faculty of the College of Pharmacy that in this three-year course we could allow students, who planned to go into retail pharmacy, opportunity to elect certain business administration courses that would better prepare them for the business side of pharmacy. We therefore arranged with the College of Business Administration to have our students admitted, first, into a course in economics as a basis for future training and, later, into courses in business law and accounting. We then extended the curriculum to one of four years combining business training with pharmacy. This curriculum would of course in no way supplant our four-year scientific course. We thought that if 1500 students would attend a College of Business Administration for four years of training to enter purely business pursuits, possibly pharmacy students would come for four years to secure a combined professional and business training. This opinion has been fully justified by the number who expect to complete this four-year combined course. Courses in salesmanship, advertising, business management, money and banking, income tax, etc., are open to pharmacy students.

The change to a minimum three-year curriculum has allowed us to more than double the amount of prescription training that a student can obtain. This work we wish particularly to emphasize. We have increased the work in manufacturing pharmacy by one-half, have extended the work in drug assay and have been able to place in the third year the courses that demand the prerequisite training of the first and second years.

The change in curriculum has stimulated the interest of our present sophomore class and many have stated that they do not want to receive a two-year degree next June but will come back for a third year so as to be as well prepared as our present freshman class will be when it graduates. A considerable number of our students have also stated that if they are to complete three years for a degree why not come full four years and receive a bachelor's degree, one that will always mean something to them? We therefore confidently expect greatly increased junior and senior classes. We are now looking forward to a time in the near future when we will have the normal number of seniors left out of a freshman class that any other four-year course in liberal arts, science or engineering has and then we will offer only a four-year course in pharmacy in this college. The pharmacists of the state of Washington join with the University in desiring quality in training rather than quantity in graduates.

We also find that our graduate work leading to the Master of Science degree is developing much interest among underclassmen. Seniors, juniors and even sophomores and freshmen come to members of the faculty and discuss the opportunities for graduate work and the openings for men with such training. 
When it is mentioned that the students as a whole seem anxious to get the best training possible and think in terms of the Bachelor's degree as being the only degree worth while, it must not be assumed that those students have unlimited means with which to go to school. Careful investigation shows that $80 \%$ of our pharmacy students are wholly or partly self-supporting and that fully $50 \%$ are wholly self-supporting. The means for carning this support cannot be discussed here but the attitude of the student is worthy of notice for it shows clearly that the lack of funds is really no bar to a student who has the interest and ambition to get the best there is.

We feel that the dropping of the two-year course has done more for this college than any other change in our plans has accomplished in many years. It has stimulated interest in pharmacy among high school principals, practical pharmacists, prospective students and among students in other colleges on the campus to a great degree. We are more than satisfied with the change and would not think of returning to the shorter course. Not one word or letter of protest has been received from a pharmacist of the state of Washington while many letters and other expressions of approval come to us for making the change.

The opinion is unanimous in this state, among persons interested, that the pharmacist should be broadly trained so that he may take his place in the community along with other broadly trained professional and business men, and that it is his duty not alone to serve the professional wants of his locality but that he should also help to serve the economic and social needs of the city in which he lives. This college of pharmacy helps to foster this idea and desires to graduate only such men and women as will realize this responsibility and take time to prepare themselves for it.

lNIVFRSITY OF WASHINGTON,

Cotilege of Pharmacy,

SEATTLE, WASHINGTON.

\section{SHALI, "PA'TEN'TS" BE INCI,UDED IN THE PHARMACEU'TICAI, CURRICULUM? \\ BY L. E. SAYRE.}

One of the most significant and far-reaching suggestions for the improvement of the profession of pharmacy is that which concerns itself with the standardization of schools and universities which offer courses leading to the degrees of Graduate in Pharmacy, Pharmaceutical Chemist and Bachelor of Science in Pharmacy. Standardization of schools and colleges has done so much to elevate the profession of medicine that any similar standardization should be very welcome to all pharmacists who love their profession and wish to see it respected by the public.

It has recently been proposed that there be included in the pharmaceutical curriculum of standardized schools a certain amount of teaching of, or the handling of, "patent medicines." This, it is assumed, is for the purpose of giving the prospective pharmacist some familiarity with the large number of proprietary articles which he later will be called upon to-I was about to say-dispense, but in the interest of truth must say "hand out."

Such a proposition, of course, assumes that patent medicines, as a side-line, or otherwise, are a necessary part of the drug stock. There are many ultra-pro- 
fessional pharmacists who would dissent from this assumption. One professional pharmacist recently made this remark to the writer: "Patents are evils-mostly unnecessary; they deceive buyer, seller, and usually the patient-why not ignore them? At least, do not let ourselves be drawn into any consideration of them that can be profitably avoided." With this assertion doubtless the average physician will agree. The physician if not the loud objector nevertheless winces at the thought of his field being lessened by the dispensing of an unknown drug combination, the value of which depends upon the favorable psychology which advertising produces. It goes without saying that these products are just as good after the psychological boost is withdrawn as before, but from a business point of view they are comparatively dead stock. 'This psychological fact should require no special call for instruction in a pharmaceutical curriculum.

At first thought the suggestion above mentioned seems reasonable and, no doubt, the information received would be of a great deal of practical interest to the young student who is seeking to master the details of the ultra-practical side of his profession, yet on second thought we are struck with the inconsistencies which will inevitably result if we admit the teaching of "patent drugs" into our curriculum, and exclude a score of other quite as worthy subjects, from the viewpoint of certain pharmacists at least.

The retail drug store of to-day is a most curious medley. We may well affirm, without fear of serious contradiction, that every druggist in the United States carries at least some one of thousands of merchantable items manufactured in this country at the present time. Our list must include machinery, dry goods, clothing, groceries, bicycles, photographic supplies, radio outfits, phonographs, as well as others. The truth is that the pharmacist sells practically everything that is to be sold and "patents" are by no means the most important package lines which many druggists handle. Commercially, no school of pharmacy can ever hope to acquaint its students with the many important ramifications of the retail drug business. When it comes to the choosing of package medicines rather than one of fifty other important side-lines I am reminded of Browning's words:-

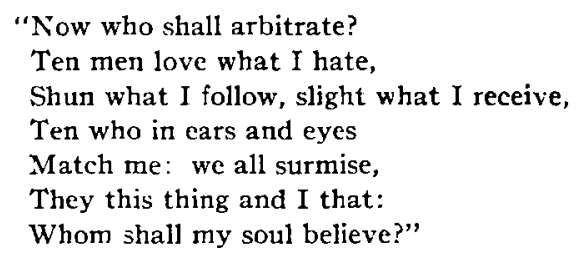

'Io repeat: when we step outside of the narrow confines of strictly professional pharmacy we are at once confronted with the dilemma as to what to include and what not to include. From a professional point of view pharmacy concerns itself with the preparation and compounding of drugs, with the direction of the strength and purity of these drugs and medicaments. Whatever functions aside from these are added do not connect up intimately with legitimate pharmacy. It is for the above reasons that the pharmacist enjoys a professional title and monopoly from the state. The state assumes that the pharmacist has exercised certain knowledge of the compounds and preparations which he dispenses. The state presupposes this intimate knowledge as belonging to his professional equipment. 
So far as knowing the ingredients of the materials he sells is concerned, a pharmacist is no wiser in selling a patent medicine than he is in selling a piece of machinery, the mechanism of which he has not been permitted to see and the directions of which he has merely to take on faith. If the college of pharmacy is to include in its curriculum the mere enumeration of thousands of names of patented articles for no other purpose than to teach the student that such articles exist, the school of pharmacy must likewise concern itself with instructions in all of the socalled pharmaceutical side-lines. Indeed it would be far more proper to include a course in the mixing of soda water, the preparation of ham and egg sandwiches, the recital of the catalogs of Victor talking machines and a score of other important matters that might likewise be included in pharmaceutical general knowledge. So long as patent medicine is but a name of a mixture for this and that disease, it matters little how meritorious that mixture may be, and there can be no room for its inclusion in the school of pharmacy where emphasis must be put entirely on teaching those subjects that are concerned only with the professional aspects and for which the state recognizes and protects the pharmacist and gives him a monopoly to ply his trade.

When all is said and done concerning the question of teaching "patents" in the curriculum of our schools of pharmacy, we must fall back on one point previously mentioned which is fundamental to any consideration of this subject. When the state creates, upholds and legalizes the profession of pharmacy and gives to the pharmacist certain rights not enjoyed by other men, it assumes that a certain knowledge and training are given to the young men and women who enter the ranks of this calling. The function of our schools of pharmacy must, therefore, be primarily to impart basic professional information. Unless we are ready to admit, and few of us can, that the professional content of pharmacy is exhausted, digested and mastered, so to speak, in the regular undergraduate two-, three- and four-year courses, we cannot uphold the inclusion of any seemingly extraneous material. This does not mean, however, that the student should not be made familiar with the various institutions and interests contributory to the vocation of pharmacy, such as the manufacturers' association, the proprietors' association, their codes of ethics and their spheres of activity.

The present curriculum, as usually carried out in our leading schools of pharmacy, contains sufficient information concerning "Commercial Pharmacy" to make all of these points clear and to give the student the psychological outlook which he must have when he enters his vocation. 